\title{
Interacting effects of change in climate, human population, land use, and water use on biodiversity and ecosystem services
}

\author{
Bodil Elmhagen $^{1}$, Georgia Destouni $^{2,3}{ }^{\text {Anders Angerbjörn }}{ }^{1}, \underline{\text { Sara Borgström }}^{4}$, Emily Boyd $^{4,5}$, Sara A. O. Cousins $^{2}, \underline{\text { Love Dalén }}^{6}$, \\ Johan Ehrlén $^{7}$, Matti Ermold $^{2}$, Peter A. Hambäck ${ }^{7}$, Johanna Hedlund $^{1}$, Kristoffer Hylander ${ }^{7}, \underline{\text { Fernando Jaramillo }}^{2}$, Vendela K.

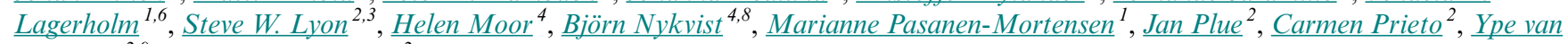 \\ der Velde $^{2,9}$ and Regina Lindborg ${ }^{2}$
}

ABSTRACT. Human population growth and resource use, mediated by changes in climate, land use, and water use, increasingly impact biodiversity and ecosystem services provision. However, impacts of these drivers on biodiversity and ecosystem services are rarely analyzed simultaneously and remain largely unknown. An emerging question is how science can improve the understanding of change in biodiversity and ecosystem service delivery and of potential feedback mechanisms of adaptive governance. We analyzed past and future change in drivers in south-central Sweden. We used the analysis to identify main research challenges and outline important research tasks. Since the 19th century, our study area has experienced substantial and interlinked changes; a $1.6^{\circ} \mathrm{C}$ temperature increase, rapid population growth, urbanization, and massive changes in land use and water use. Considerable future changes are also projected until the mid-21st century. However, little is known about the impacts on biodiversity and ecosystem services so far, and this in turn hampers future projections of such effects. Therefore, we urge scientists to explore interdisciplinary approaches designed to investigate change in multiple drivers, underlying mechanisms, and interactions over time, including assessment and analysis of matching-scale data from several disciplines. Such a perspective is needed for science to contribute to adaptive governance by constantly improving the understanding of linked change complexities and their impacts.

Key Words: governance; historical ecology; landscape management; scale mismatch; social-ecological systems

\section{INTRODUCTION}

Human population growth and industrialization of agriculture have been major drivers of Earth system change since the late 18 th century, increasing the species extinction rate substantially above the background level (MEA 2005, Steffen et al. 2007). This biodiversity loss has changed the structure and function of ecosystems, which has impacted humanity in terms of altered ecosystem service delivery (Cardinale et al. 2012, Mace et al. 2012). Several ecosystem services are currently declining in response to human activity at local, regional, and global scales, e.g., nutrient and water retention because of wetland drainage and pollination because of loss of natural habitats (Carpenter et al. 2009, Foley et al. 2011).

Climate change is currently the main focus on the environmental politics agenda (IPPC 2007). However, although climate change is expected to become an important driver of biodiversity change in the 21 st century, land use is projected to remain the main driver of change (Sala et al. 2000). Furthermore, change in land use often parallels change in water use, which in turn drives and feeds back to hydro-climatic change on different spatial and temporal scales (Lee et al. 2011, Jarsjö et al. 2012, Destouni et al. 2013). Projected future change in these drivers and biodiversity accentuates the need to further develop the ecosystem service framework to better incorporate the values of natural capital into decision-making processes (MEA 2005, TEEB 2010). The high degree of uncertainty increases the need for adaptive governance, including processes of governing such as market forces and networks at multiple scales, and governing through various institutions (Bevir 2013). "Adaptive" implies that the governance is characterized by flexibility and learning in response to environmental crisis (Folke et al. 2005). However, with the exception of large-scale national projects for which interdisciplinary assessments are crucial (e.g., Kautsky et al. 2013), these governance challenges and the potentially synergistic effects of multiple drivers on biodiversity (Brook et al. 2008) are rarely analyzed simultaneously. This lack of integrative studies raises the question of how well the scientific community understands the processes underlying change in biodiversity, ecosystem functions, and ecosystem services (Naeem et al. 2012), and consequently whether future projections can be used to inform decision making (Olsson et al. 2010).

In this paper, we specifically address the question of what constitutes a useful research approach to investigate change in biodiversity and ecosystem services. We used the intensively cultivated and urbanized Norrström drainage basin (NDB) in south-central Sweden to (1) analyze how the potentially important drivers climate, human population, land use, and water use (henceforth land-water use) have changed since the mid-19th century and are likely to change until the mid-21st century; (2) identify research challenges at different spatiotemporal scales related to linkages between changes in these drivers and changes in biodiversity and ecosystem service delivery; and (3) outline

\footnotetext{
${ }^{1}$ Stockholm University, Department of Zoology, ${ }^{2}$ Stockholm University, Department of Physical Geography, ${ }^{3}$ Stockholm University, Bert Bolin Centre for Climate Research, ${ }^{4}$ Stockholm University, Stockholm Resilience Centre, ${ }^{5}$ University of Reading, School of Archaeology, Geography and Environmental Sciences, ${ }^{6}$ Swedish Museum of Natural History, Department of Bioinformatics and Genetics, ${ }^{7}$ Stockholm University, Department of Ecology, Environment and Plant Sciences, ${ }^{8}$ Stockholm Environment Institute, ${ }^{9}$ Wageningen University, Department of Soil Geography and Landscape
} 
research tasks showing how interdisciplinary research can enhance our understanding of these linkages and feedback effects of governance.

\section{METHODS}

\section{Study region}

The NDB covers $22,650 \mathrm{~km}^{2}$ and is located at the interface between the boreo-nemoral mixed-forest biome and the boreal coniferous forest biome $\left(15^{\circ} \mathrm{N}, 17^{\circ} \mathrm{E}\right.$; Fig. 1). The boreo-nemoral biome is globally vulnerable because of far-reaching habitat conversion relative to the low proportion of protected habitat (Hoekstra et al. 2005). During the latest ice age, the ice sheet suppressed NDB below sea level. Approximately 5000 years ago, land uplift raised NDB above sea level and the land was colonized by humans practicing farming. Hence, the region has a continuous history of anthropogenic impact, primarily through subsistence agriculture (Barthel et al. 2005). The agrarian revolution reached Sweden in the 19th century, when mechanization of agriculture indirectly allowed urbanization and industrialization. These processes were associated with land-use changes that culminated in the 1930s (Cousins 2009). Present land use in NDB is dominated by forestry and intense crop production, with scattered remnants of seminatural grasslands and deciduous woodlands (Sporrong 2008, Cousins 2009).

Fig. 1. Location of the study area, the Norrström drainage basin (NDB), in south-central Sweden.
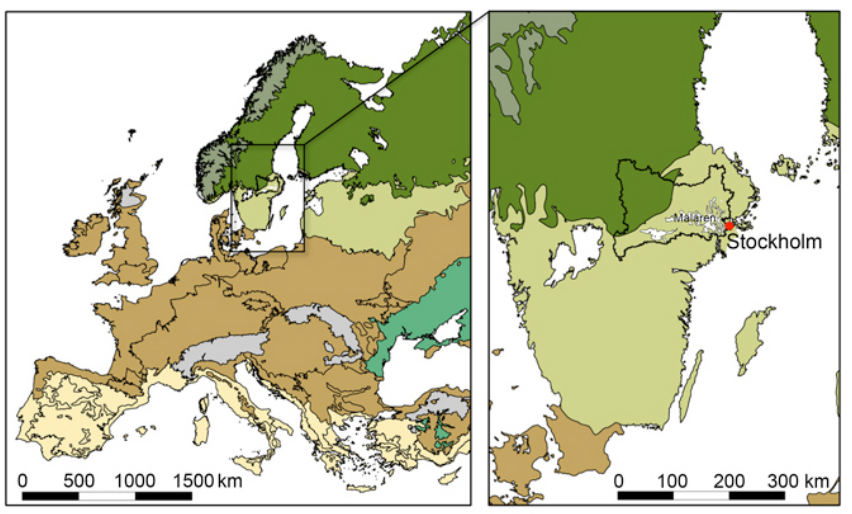

$\square$ Nemoral zone

$\square$ Boreo-nemoral zone
NDB comprises 6 county administrative boards and 54 municipalities. A significant part of Stockholm, the capital of Sweden, and its suburbs are located within NDB, making it one of the most densely populated basins in Sweden (Darracq et al. 2005). NDB includes Sweden's third largest lake, Mälaren, which provides a regional ecosystem service by supplying nearly 2 million people with drinking water (Darracq et al. 2005). NDB is a key area regarding nutrient loading into the Baltic Sea because of intense agricultural activity and a large human population. In an international perspective, NDB stands out because of a history of long-term urbanization, a long tradition of urban planning, and present export of urban planning ideals to other regions with rapid urbanization (Borgström 2011).

\section{Changes in drivers}

To analyze past change in climate and the human population and land-water use, we compared the mid-19th century with the present time. In the mid-19th century, land use and the distribution of the human population should still largely reflect the time before the agrarian revolution. It is also a time when the collection of official statistics increased substantially following the establishment of Statistics Sweden in 1858. For example, the number of national weather stations measuring temperature increased from 4 to 31 in the early 1860 s. Likewise, yearly reports on agriculture were published from 1865 onward, although the level of detail varied.

To analyze past and present climate in NDB, we retrieved measured data on mean monthly temperature from all temperature stations operating in the region in 1861-1890 and 1981-2010 from the Swedish Meteorological and Hydrological Institute. Thirty years is a well-established climatic norm, i.e., the time period generally used to describe prevailing weather conditions. For the period 1981-2010, for which many stations are available, we determined monthly relationships between temperature and elevation and distance to the Baltic Sea (Vercauteren et al. 2013). We assumed that these relationships did not change between 1860 and 2000, and used them to interpolate (krige) temperature between the five temperature stations operating in the period 1861-1890, thus taking into account elevation and distance to the Baltic Sea in the interpolation. To compare present climate (1981-2010) with projected future climate (2041-2070), we used information from 13 regional climate models combined with 10 global climate models into 24 model runs downloaded from the ENSEMBLES archive (http:// www.ensembles-eu.org/; van der Velde et al. 2013). From these models we calculated the ensemble mean and range for monthly temperatures, as well as the ensemble mean for yearly temperatures. Ensemble means are more reliable than single model projections (Jarsjö et al. 2012, van der Velde et al. 2013).

We retrieved data on the human population and land use from Statistics Sweden. Most early reports present statistics at the level of counties, but reports concerning 1865 include finer spatial scales. Hence, we used data from 1865 to represent the mid-19th century. Data on population size were then available for towns and judicial districts (Statistics Sweden 1867). Recent data (1990-2010) were available for densely built areas and municipalities (downloaded from Statistics Sweden http://www. scb.se/). In 1865 the smallest town in NDB had 504 inhabitants. For consistency, we defined densely built areas as urban when they had more than 500 inhabitants. We calculated rural population density for each judicial district or municipality. To project the population in 2045, we fitted linear mixed-effect models to the 1990-2010 data on rural population density and urban population size, modeling municipality and urban area as random effects. The fitted models explained $>99 \%$ of the variation in the data, and we used the fitted equations for the random effects to project the population in 2045. The Stockholm region, i.e., Stockholm city and nearby municipalities with transboundary urban areas, was an outlier because of its large population. Hence, we fitted and projected a separate linear model for this region. The fitted model explained $96 \%$ of the variation in the data. 
Fig. 2. Climate, human population, and land use in NDB in the 19th century and at present (2000s), as well as climate and human population projections for the mid-21st century. a) Mean annual temperature and temporal distribution of monthly mean temperature. Figures to the left and middle/left show measurement points (temperature stations) and mean temperature calculated as gridded interpolations between measurement points. Figures to the right and middle/right show ensemble mean temperature (and spreading around the mean) for 24 climate model projections. b) Human population density in rural areas and population size in densely-built areas. c) The proportion of cropland in judicial districts (1865) and municipalities (2005).

(a) Temperature 1861-1890
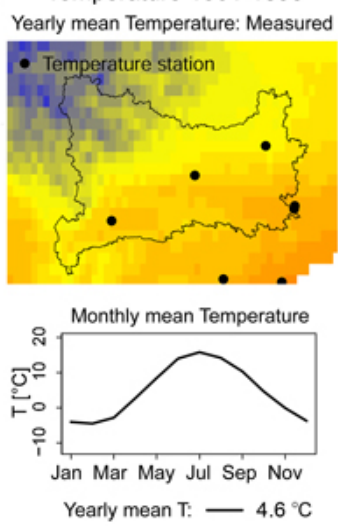
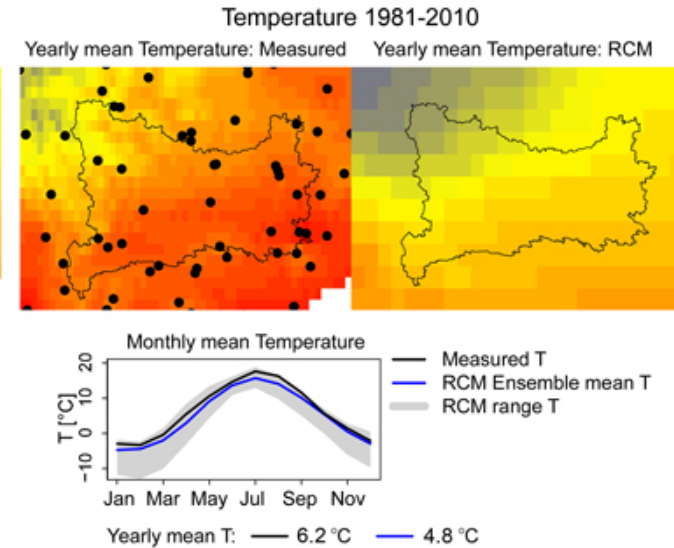

Temperature 2041-2070
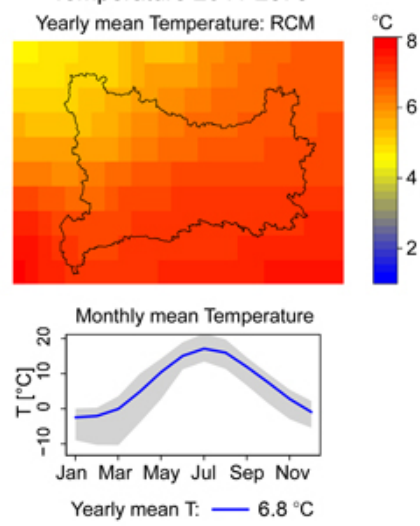

(b)

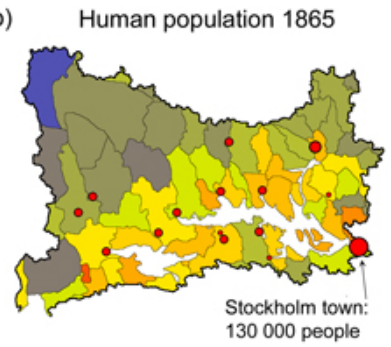

(c)

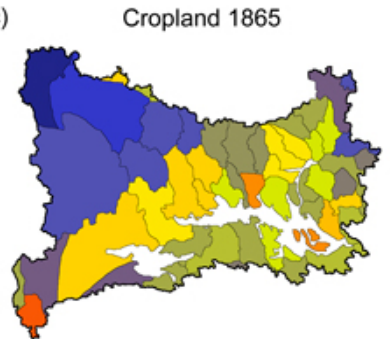

Human population 2005

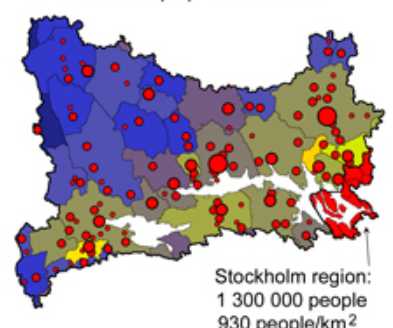

1300000 people

No. of peoplein

- 500-999

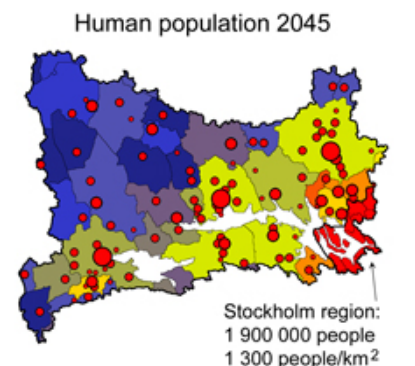

1300 people $/ \mathrm{km}^{2}$

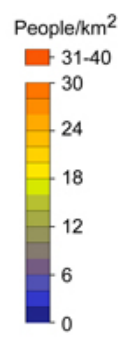

People/km

s or densely-built areas with $>500$ peopl -1000-9999 - 10 000-99 999

$100000-200000$

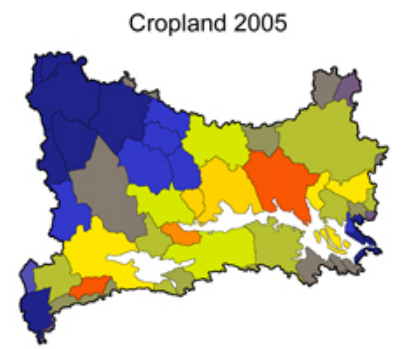

We used data on cropland area as a proxy for land-water use intensity in each district or municipality to represent past and present land use. In contrast to other land-cover classes, such as the seminatural grasslands that were an important feature in the mid-19th century landscape, data on cropland area were reported in a consistent manner. We used published data from 1865 (Statistics Sweden 1868) and downloaded data from 2005 (from Statistics Sweden). We complemented this assesement with a brief literature review on changes in land-water use in NDB.

\section{HISTORICAL AND FUTURE CHANGE IN DRIVERS IN NDB}

\section{Climate}

The measured mean annual temperature in NDB was lower in the mid-19th century than at present: $4.6^{\circ} \mathrm{C}$ in $1861-1890$ and $6.2^{\circ} \mathrm{C}$ in 1981-2010. As for present temperatures, the ensemble result of 24 climate models systematically underestimated the current temperature by approximately $1.4^{\circ} \mathrm{C}$ compared with measured temperature (Fig. 2a; 1981-2010). By 2041-2070, the mean 
projection of the models suggests a $2.0^{\circ} \mathrm{C}$ increase in mean annual temperature compared with the temperature estimated for 1981-2010. If the projection correctly represents the degree of increase, we can expect an increase in measured temperatures from the current annual mean of $6.2^{\circ} \mathrm{C}$ to $8.2^{\circ} \mathrm{C}$.

There is substantial annual to decadal variation around any longterm temperature trend. Comparisons between specific time periods should therefore be interpreted with caution. Nevertheless, an assessment of global temperature trends in 1901-2012 suggests a mean increase of $0.8-1.5^{\circ} \mathrm{C}$ in the NDB region, whereas the mean global increase was $0.89^{\circ} \mathrm{C}$ (IPCC 2013). Thus, there is considerable support for a warming climate trend in NDB. Our analyses indicate that northwestern NDB had lost its boreal climate conditions by the end of the 20th century (Fig. 2a). Continued warming to a mean annual temperature of $8.2^{\circ} \mathrm{C}$ could imply a loss of boreo-nemoral climate conditions by the mid-21st century. During the climatic normal period in 1961-1990, a mean annual temperature of $7-8^{\circ} \mathrm{C}$ characterized the nemoral vegetation zone in Sweden (SMHI 2013), which is located $500 \mathrm{~km}$ south of NDB (Fig. 1).

\section{Human population}

The human population in NDB tripled in size between 1865 and 2005 , from 807,000 to 2.6 million people. This was a period of urbanization as well as depopulation of rural areas. In 1865, 22\% of the population lived in towns, whereas $90 \%$ were urban in 2005 . Only $6 \%$ of the districts had a rural population density of fewer than 10 people $/ \mathrm{km}^{2}$ in 1865 , compared with $49 \%$ of the municipalities in 2005 (Fig. 2b). Projections suggest that several urban areas will continue to grow (Fig. 2b). For example, the Stockholm region will increase from $1,290,000$ people to $1,850,000$ ( $\mathrm{SE} \pm 110,000$ ) by 2045. In southeastern NDB, population densities also are projected to increase in rural areas, possibly because of urban sprawl with people commuting between work in urban areas and countryside homes. In contrast, depopulation of northeastern NDB is projected to continue, both in rural areas and small urban areas (Fig. 2b).

In a global perspective, NDB has a high degree of urbanization. Approximately $50 \%$ of the global population was urban in 2010, and this is projected to increase to $60 \%$ by 2030 (Grimm et al. 2008). Similar to NDB, however, a large part of the global urban population is expected to live in relatively small urban areas rather than in megacities with more than 10 million inhabitants (Cohen 2004).

\section{Land-water use}

There was $18 \%$ cropland in the NDB landscape in 1865 , ranging from $2 \%$ to $45 \%$ at the district level. In 2005 there was $16 \%$ cropland, ranging from $0 \%$ to $48 \%$ at the municipality level (Fig. 2c). Although there was little change in the total amount of cropland, its spatial distribution changed. The proportion of cropland was higher around Lake Mälaren in 2005 than in 1865, but lower in the low-productivity Northeast and the urbanized Stockholm region (Fig. 2c).

Human population growth and urbanization were associated with substantial land-use changes in Sweden (Antonsson and Jansson 2011). The mid-19th century landscape was shaped by subsistence food production. A typical farm in NDB had relatively small crop fields and large areas of grazed semiopen grasslands (Fig. 3;
Cousins 2009). Forests were grazed by livestock and relatively open (Emanuelsson 2010). Old forests were also rare because of a regional iron extraction industry and an associated need of fuel wood. From the mid-19th century, wet and moist habitats were drained to increase production (Antonsson and Jansson 2011). Efficient ploughs allowed cultivation of clay-rich soils, which were transformed from grassland to cropland. The amount of cropland increased until the 1930s, after which less productive arable land was converted to forest (Cousins 2009). To promote forest growth and silviculture, livestock grazing in forests was banned in the 1930s. In productive regions, e.g., around Lake Mälaren, most traditional farms were merged into larger and intensively managed farms with high use of fertilizers and pesticides, a process that still is ongoing (Nykvist 2014). Both evapotranspiration and variation in daily runoff increased with cropland area and crop production in the early 1900s, but then stabilized or decreased. This change suggests that increased crop production was associated with greater water use that altered the water circulation in the landscape, despite the fact that irrigation is rare in NDB (Destouni et al. 2013, van der Velde et al. 2014). Moreover, urbanization and agricultural intensification have led to water pollution and eutrophication in NDB and coastal waters in the Baltic Sea (Darracq et al. 2008).

Fig. 3. Photos from NDB representing a) a traditional agricultural landscape, common in the late 1800 s, with seminatural grasslands and relatively small crop fields, and b) an agriculture landscape dominated by crop fields, common at present. Photos by S. Cousins.

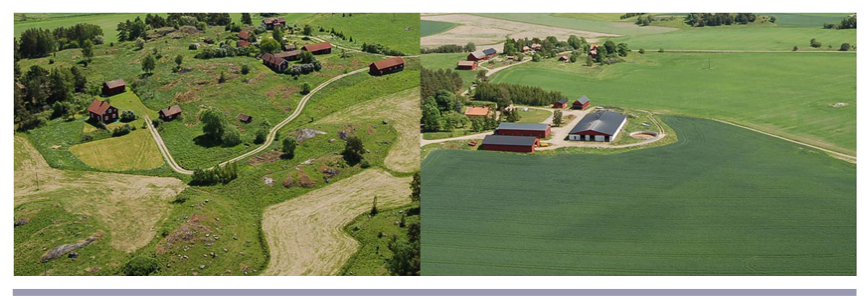

Since the mid-19th century, mechanization of agriculture, human population growth, and urbanization have been important drivers of land-use change in NDB. Our projection of human population growth suggests that urbanization will continue. This urbanization could maintain the trend of decreasing cropland area in low-productivity regions. However, several other scenarios may arise depending on local and national policies, e.g., increased demand for locally produced food, and global issues such as higher energy prices. Likewise, from the perspective of climate change, NDB may face substantial changes in landscape composition because warming may improve the potential for agricultural production. At a global level, human population growth also reinforces the demand for increased land-water use to increase production of food and energy (FAO 2009). Hence, low-productivity soils within NDB, which have been forested since the 1930s (Cousins 2009), might be reclaimed for agricultural production. This would encourage development of a landscape dominated by intense forestry and agriculture. Increased water use for agriculture and energy production in upstream parts of the basin might in turn change the water flow and downstream potential for fisheries and other ecosystem services (Destouni et al. 2013). Several changes in land-water use in NDB since the 19th 
century were nonlinear. Likewise, a number of future scenarios are possible, making it difficult to project changes in land-water use.

\section{IDENTIFYING RESEARCH CHALLENGES}

\section{Links between drivers and change in biodiversity and ecosystem services}

In the last century, habitat changes because of intensified food and forest production have been the main driver of global biodiversity change, with human harvesting as a contributing factor (Sala et al. 2000, Foley et al. 2011). Now, climate change has started to affect the phenology and distribution of species (Parmesan and Yohe 2003). In addition, substantial interactions and synergies between different drivers of change are likely (Brook et al. 2008). Our analysis shows that NDB has experienced major historical changes in climate, human population, and landwater use. The present knowledge on biodiversity responses is scattered, but suggests extensive changes. For example, a study partly focused on NDB shows that seminatural grasslands covered $46 \%$ of the landscape a century ago compared with $2 \%$ today. These species-rich grasslands have primarily transitioned to low-diversity conifer forests (Cousins et al. 2015). Likewise, $38 \%$ of the Swedish bird species declined over the last 30 years, in particular farmland species connected to the past landscape (Ottvall et al. 2009). However, bird species that benefit from warmer conditions have increased in abundance, while northern species have declined (Lindström et al. 2013). Climate warming is also affecting the phenology of species; 45 of 66 investigated butterfly species have advanced their flight dates (Karlsson 2014). The wildlife has been affected by harvest and management, leading to extirpation and recolonization of both ungulates and large carnivores since the 19th century. Large carnivore extirpation favored ungulate recolonization and increased numbers of European red fox (Vulpes vulpes), and increased fox abundance probably suppressed small game such as hare and grouse (Elmhagen and Rushton 2007, Liberg et al. 2010). Nevertheless, the fox and recolonizing ungulates such as roe deer were also favored by land-use changes and climate warming (Liberg et al. 2010, Pasanen-Mortensen 2014).

Similar to biodiversity change, assessments of past ecosystem service delivery in NDB are not available. However, Andersson et al. (2015) show that changes in the size and distribution of the human population, as well as in value systems, policies, and priorities, generally alter the societal demand for and use of certain services. Urbanization and globalization allowed a transition from a landscape dominated by rural subsistence farming to one characterized by commercial farming and forestry, and this has also changed the linkages of local and regional ecosystems. A study assessing present-time ecosystem services in NDB found that the distribution of 16 ecosystem services varied substantially across the landscape (Quieroz et al. 2015). Although regulating services were evenly distributed, cultural services were dominant near the Stockholm metropolitan region, except for hunting and outdoor recreation. The provisioning services from agriculture, together with the regulating service pollination, were clustered around the large lakes. It was also found that the agricultural areas are highly multifunctional, with fewer tradeoffs between provisioning and other ecosystem services compared with other case studies (Quieroz et al. 2015).
To summarize, we suggest that although there has been no comprehensive assessment of past changes in biodiversity and ecosystem service delivery in NDB since the 19th century, extensive changes have occurred in response to a number of interacting drivers. The emerging question is how we can investigate these responses in informative detail and at appropriate spatiotemporal scales.

\section{Gaps in data availability and knowledge}

A main challenge in improving ecosystem governance is to understand key mechanisms of change for multiple drivers, such as climate and land-water use, and how these affect biodiversity and ecosystem service delivery (Rockström et al. 2009a). How to achieve this understanding is a key research question because linkages between biodiversity and ecosystem services remain largely unknown (Cardinale et al. 2012). Even less is known about the combined impacts of changes in climate, land-water use, and biodiversity on the future supply of ecosystem services (HainesYoung 2009). Based on our analysis of past and potential future change in NDB, we found two main research obstacles: (1) low availability of data at matching temporal and spatial scales and (2) uncertainties in future projections, in particular connected to uncertainties regarding future local-to-global social-ecological development.

The data used in our analyses were available from national databases and publications, but they provided sparse spatial coverage or were reported for large areas only. Climate monitoring increased over time, but the spatial coverage of temperature stations remained sparse (Fig. 2a). Hence, only regional climate change can be assessed. This limitation makes it difficult to investigate the effects of climate change on the spatial scales of main importance for sedentary species, because local temperature variation due to topography and land-water use can be substantial. The resolution in climate models is often coarse, and the local climate to which organisms respond can differ considerably from the mean over a larger area (Dobrowski et al. 2009). In NDB, present climate models also underestimate current regional temperatures, although model projections might capture the relative degree of future change. Furthermore, because temperature and precipitation can change along different trajectories (Bring and Destouni 2011), it might be valuable to take several climate variables into account. In NDB, long-term data on temperature as well as on precipitation and water flow are available (Destouni et al. 2013), but in many other areas the temporal extent of such data is considerably shorter (Koutsouris et al. 2010, Bring and Destouni 2011).

Data on human population size and land cover were often reported as summary statistics for counties, which is a substantially larger spatial scale than districts/municipalities. Furthermore, the reported land-cover categories changed over time. Present land-cover data are available for the whole of Europe (CORINE land-cover data with a resolution of $50 \times 50 \mathrm{~m}$; $\underline{\mathrm{http}}: / /$ www.eea.europa.eu/data-and-maps/data/corine-land-cover-2000clc2000-seamless-vector-database), but historical land-use data are not available at similarly large geographical scales. Detailed historical maps are generally available only for local farming regions (Cousins and Eriksson 2002), similar to the situation in other parts of Europe (Krauss et al. 2010). Scale mismatches in data also affect assessments of water-use change. Across regions, 
there are disparities between areas covered by hydrological monitoring and areas with substantial pressure from eutrophication and pollution (Hannerz and Destouni 2006) or climate change (Bring and Destouni 2011). Substantial variation in land cover and water conditions makes it both essential and difficult to assess hydro-climatic changes at the scales relevant for water governance (Koutsouris et al. 2010). For land-cover/use data, there is also generally a mismatch between the scale at which land use is reported and the scale relevant for governance affecting biodiversity and ecosystem services (Andersson et al. 2015).

There is a need to assess more detailed historical data on biodiversity and ecosystem services to enable improved and more informative analyses of past change. There are some official data on economically important species, e.g., carnivore bounties and qualitative information on the status of game species, but they are often reported for entire counties (e.g., Statistics Sweden 1879). For the majority of taxa, there is little time- and site-specific documentation. The historical archives in Sweden may contain more information and data on finer spatiotemporal scales, including museum collections and hand-written documents underlying published reports. Assessing and publishing this information would be a valuable area of future interdisciplinary research (cf. Kardell and Dahlström 2013). Change in ecosystem service delivery is even more difficult to predict from historical data because it is a relative new component in change analyses. Few studies have directly assessed its development over time (Malinga et al. 2013), with the exception of some provisioning services like timber and food production that are monitored yearly at the regional or national level. Moreover, change assessments of ecosystem services typically address only one service linked to a certain ecological process, e.g., pollination or nutrient retention by vegetation (Nowak et al. 2006, Norris 2011, Andersson et al. 2012).

Future projections inherently involve large uncertainties. We projected changes for variables for which we could provide an ensemble mean for several predictive models, e.g., temperature, or for which past trends were strongly linear, e.g., human population growth. The high level of inertia generally shown in human population growth suggests that a projection over a few decades is fairly reliable, although it could be overthrown by changed migration patterns. In contrast, past changes in landwater use were nonlinear because of local-to-global changes in social-ecological conditions. This means a number of future scenarios are possible. The high degree of uncertainty underlines the necessity of adaptive governance involving flexibility and learning (Folke et al. 2005). That in turn highlights a need for interdisciplinary research linking changes in biodiversity and ecosystem services and governance.

\section{FUTURE INTERDISCIPLINARY RESEARCH TASKS}

Our analysis of change in NDB suggests that a major future task is to compile data on matching scales and investigate links and feedback mechanisms between different drivers of change, including governance. Such an undertaking has broad research interest, because biological processes generally have been studied on smaller scales than those relevant for management and policy (Cardinale et al. 2012, Scholes et al. 2013). Formulation of research approaches designed to evaluate mechanisms and their interactions at regional-to-local scales are especially relevant across regions with complex social-ecological systems, e.g., regions experiencing rapid human population growth along with urbanization and land-water use pressures and those where climate change is likely to impact these and other components of change.

A first task is to assess data at matching scales. These include historical data, e.g., historical maps and climate data. To account for different scales, new approaches must be developed and tested for scale transition and bias correction. For example, results from global and regional climate models must be transitioned to the scales relevant for change assessment of land-water use and water flow, availability, and quality (Jarsjö et al. 2012), as well as to the scales relevant for biological and societal processes. Likewise, historical maps should be used to reconstruct historical landscapes over large areas. Because maps generally are biased toward productive and agricultural regions, it is necessary to find methods to interpolate between mapped areas using, for example, information on how land use was related to different soils at different times and in different regions (Cousins 2009, PasanenMortensen 2014). To increase the availability of data on historic species distributions and population trends, interdisciplinary work needs to involve historians who are skilled at finding and interpreting material such as archived hand-written documents.

A second task is to study biodiversity responses to changes in climate, land-water use, and other human drivers at various scales. For example, it is not well known to what extent species redistribute themselves to suitable microclimates within a landscape during inhospitable climate periods (Ashcroft et al. 2009), nor to what extent land use constrains the possibility of a landscape to house such topoclimatic refugia. This requires investigation of small-scale variation in drivers in relation to the distribution of sedentary species in particular, and their genetic composition across landscapes. We also need to investigate how drivers impact species and their interactions at larger spatial scales. When historical data on drivers and species trends are available on matching scales, these can be analyzed directly (cf. Elmhagen and Rushton 2007). However, time-for-space approaches, i.e., approaches in which spatial relationships between drivers and biodiversity are analyzed as a substitute for temporal relationships, should be used as a complement. These approaches can be used to investigate the impact of past changes on species abundance and ecosystem structures (PasanenMortensen 2014). When we focus on particular model ecosystems, wetlands may provide a particularly interesting case, with linkages to hydro-climatic conditions, greenhouse gas emissions, biodiversity, and various ecosystem services. To date, there are few examples of sustainable ecosystem management of wetlands because of incomplete understanding of the underlying mechanisms or because of a focus on specific goods rather than processes that sustain ecosystem functioning (Euliss et al. 2008).

A third task is to link ecosystem service delivery to governance dynamics and other investigated changes, e.g., agricultural intensity (Norris 2011), hydro-climate (van der Velde et al. 2014), and/or land-water use and other socioeconomic sectors (Baresel and Destouni 2005). Studying how different farming systems affect ecosystem services and biodiversity composition can help us to understand the mechanism that drives changes through time (Fischer et al. 2008, Milestad et al. 2010, Andersson et al. 2015). 
Finding efficient ways of assessing how multiple ecosystem services are coupled to each other in "bundles" is also a research gap to bridge in studies of ecosystem services (Bennet et al. 2009, Carpenter et al. 2009, Quieroz et al. 2015). To cope with the inherent nested nature of ongoing and future changes in climate, land-water use, biodiversity, and ecosystem services with their embedded nonlinearities and surprises, a high degree of adaptive capacity in human societies is needed (Ostrom 2009, Rockström et al. 2009b). It is crucial to maintain forms of governance that support flexible institutions at multiple levels that constantly improve social and ecological knowledge to be used in revised planning and management (Boyd and Folke 2011, Boyd et al. 2015). Governance should also be matched to the scales of system processes in time and space, enhancing the ability to rapidly respond and adapt to change (Cumming et al. 2013). Further investigations are needed to (1) assess the regional adaptive governance capacity to manage ecosystem services under the impact of change, (2) evaluate the potential of the ecosystem service concept to integrate ecological aspects into decisionmaking processes across scales, (3) assess the degree of scale matching at local-to-regional levels in rapidly urbanizing landscapes, and (4) explore the challenges of up-scaling and/or down-scaling of governance initiatives in relation to social and ecological system boundaries.

\section{CONCLUSION}

Land use and water use, human population, and climate have changed through time in the NDB study area, and changes in biodiversity and ecosystem service delivery may be connected to these interacting drivers. Although projections of change are fundamentally difficult to develop, e.g., because of shifts in human value systems and policies, projections are still valuable to communicate potential effects of change to decision makers and to enable development of anticipatory governance that takes projections and probable change scenarios into account (Boyd et al. 2015). To better understand changes in biodiversity and ecosystem service delivery, we urge scientists to collaborate across disciplines to explore the importance of interacting drivers and feedback mechanisms, including synthesis and assessment of matching-scale data from multiple disciplines. Through such improved interdisciplinary understanding at various spatiotemporal scales, science will be a better contributor of knowledge to support adaptive governance.

Responses to this article can be read online at: http://www.ecologyandsociety.org/issues/responses. $\mathrm{php} / 7145$

\section{Acknowledgments:}

The authors engage in interdisciplinary research financed by the Strategic Research Program EkoKlim at Stockholm University through the Swedish Research Council for Environment, Agricultural Sciences and Spatial Planning (FORMAS). Georgia Destouni and Fernando Jaramillo also acknowledge financial support from the Swedish Research Council (Vetenskapsrådet, project number 2009-3221), and Georgia Destouni and Ype van
}

der Velde from the parallel Strategic Research Program BEAM at Stockholm University. We thank three anonymous reviewers for thoughtful comments, which improved the manuscript.

\section{LITERATURE CITED}

Andersson, E., B. Nykvist, R. Malinga, F. Jaramillo, and R. Lindborg. 2015. A social-ecological analysis of ecosystem services in two different farming systems. $A M B I O$ 44(Suppl 1): S102-S112. http://dx.doi.org/10.1007/s13280-014-0603-y

Andersson, G. K. S., M. Rundlöf, and H. G. Smith. 2012. Organic farming improves pollination success in strawberries. PLOS ONE 7(2):e31599. http://dx.doi.org/10.1371/journal.pone.0031599

Antonsson, H., and U. Jansson. 2011. Agriculture and forestry in Sweden since 1900. Geographical and historical studies. The Royal Swedish Academy of Agriculture and Forestry, Malmö, Sweden.

Ashcroft, M. B., L. A. Chisholm, and K. O. French. 2009. Climate change at the landscape scale: predicting fine-grained spatial heterogeneity in warming and potential refugia for vegetation. Global Change Biology 15:656-667. http://dx.doi.org/10.1111/ j.1365-2486.2008.01762.x

Baresel, C., and G. Destouni. 2005. Novel quantification of coupled natural and cross-sectoral water and nutrient/pollutant flows for environmental management. Environmental Science and Technology 39:6182-6190. http://dx.doi.org/10.1021/es050522k

Barthel, S., J. Colding, T. Elmqvist, and C. Folke. 2005. History and local management of a biodiversity-rich, urban cultural landscape. Ecology and Society 10(2): 10. [online] URL: http:// www.ecologyandsociety.org/vol10/iss2/art10/

Bennett, E. M., G. D. Peterson, and L. J. Gordon. 2009. Understanding relationships among multiple ecosystem services. Ecology Letters 12:1394-1404. http://dx.doi.org/10.1111/ j.1461-0248.2009.01387.x

Bevir, M. 2013. Governance: a very short introduction. Oxford University Press, Oxford, UK. http://dx.doi.org/10.1093/ actrade/9780199606412.001.0001

Borgström, S. 2011. Urban shades of green. Current patterns and future prospects of nature conservation in urban landscapes. Dissertation. Stockholm University, Stockholm, Sweden.

Boyd, E., and C. Folke, editors. 2011. Adapting institutions: governance, complexity and social-ecological resilience. Cambridge University Press, Cambridge, UK. http://dx.doi.org/10.1017/ CBO9781139017237

Boyd, E., B. Nykvist, S. Borgström, and I. A. Stacewicz. 2015. Anticipatory governance for social ecological resilience $A M B I O$ 44(Suppl 1):S149-S161. http://dx.doi.org/10.1007/s13280-014-0604$\underline{\mathrm{x}}$

Bring, A., and G. Destouni. 2011. Relevance of hydro-climatic change projection and monitoring for assessment of water cycle changes in the Arctic. $A M B I O$ 40:361-369. http://dx.doi. org/10.1007/s13280-010-0109-1

Brook, B. W., N. S. Sodhi, and C. J. A. Bradshaw. 2008. Synergies among extinction drivers under global change. Trends in Ecology \& Evolution 23:453-460. http://dx.doi.org/10.1016/j.tree.2008.03.011 
Cardinale, B. J., J. E. Duffy, A. Gonzalez, D. U. Hooper, C. Perrings, P. Venail, A. Narwani, G. M. Mace, D. Tilman, D. A. Wardle, A. P. Kinzig, G. C. Daily, M. Loreau, J. B. Grace, A. Larigauderie, D. S. Srivastava, and S. Naeem. 2012. Biodiversity loss and its impact on humanity. Nature 486:59-67. http://dx.doi. org/10.1038/nature 11148

Carpenter, S. R., H. A. Mooney, J. Agard, D. Capistrano, R. S. DeFriese, S. Díaz, T. Dietzg, A. K. Duraiappah, A. OtengYeboah, H. M. Pereira, C. Perrings, W. V. Reid, J. Sarukhan, R. J. Scholes, and A. Whyte. 2009. Science for managing ecosystem services: beyond the Millennium Ecosystem Assessment. Proceedings of the National Academy of Sciences of the United States of America 106:1305-1312. http://dx.doi.org/10.1073/ pnas.0808772106

Cohen, B. 2004. Urban growth in developing countries: a review of current trends and a caution regarding existing forecast. World Development 32:23-51. http://dx.doi.org/10.1016/j.worlddev.2003.04.008

Cousins, S. A. O. 2009. Landscape history and soil properties affect grassland decline and plant species richness in rural landscapes. Biological Conservation 142:2752-2758. http://dx.doi. org/10.1016/j.biocon.2009.07.001

Cousins, S. A. O., A. G. Auffret, J. Lindgren, and L. Tränk. 2015. Regional-scale land-cover change during the 20th century and its consequences for biodiversity. AMBIO 44(Suppl 1):S17-S27. http://dx.doi.org/10.1007/s13280-014-0585-9

Cousins, S. A. O., and O. Eriksson. 2002. The influence of management history and habitat on plant species richness in a rural hemiboreal landscape, Sweden. Landscape Ecology 17:517-529. http://dx.doi.org/10.1023/A:1021400513256

Cumming, G. S., P. Olsson, F. S. Chapin, III, and C. S. Holling. 2013. Resilience, experimentation, and scale mismatches in socialecological landscapes. Landscape Ecology 28:1139-1150. http:// dx.doi.org/10.1007/s10980-012-9725-4

Darracq, A., F. Greffe, F. Hannerz, G. Destouni, and V. Cvetkovic. 2005. Nutrient transport scenarios in a changing Stockholm and Mälaren valley region. Water Science and Technology 51:31-38.

Darracq, A., G. Lindgren, and G. Destouni. 2008. Long-term development of phosphorus and nitrogen loads through the subsurface and surface water systems of drainage basins. Global Biogeochemical Cycles 22:GB3022. http://dx.doi. org/10.1029/2007GB003022

Destouni, G., F. Jaramillo, and C. Prieto C. 2013. Hydro-climatic shifts driven by human water use for food and energy production. Nature Climate Change 3:213-217. http://dx.doi.org/10.1038/ $\underline{\text { nclimate } 1719}$

Dobrowski, S. Z., J. T. Abatzoglou, J. A. Greenberg, and S. G. Schladow. 2009. How much influence does landscape-scale physiography have on air temperature in a mountain environment? Agricultural and Forest Meteorology 149:1751-1758. http://dx.doi.org/10.1016/j.agrformet.2009.06.006

Elmhagen, B., and S. P. Rushton. 2007. Trophic control of mesopredators in terrestrial ecosystems: top-down or bottom-up? Ecology Letters 10:197-206. http://dx.doi.org/10.1111/ j.1461-0248.2006.01010.x
Emanuelsson, U. 2010. The rural landscapes of Europe: how man has shaped European nature. The Research Council Formas, Stockholm, Sweden.

Euliss, N. H., L. M. Smith, D. A. Wilcox, and B. A. Browne. 2008. Linking ecosystem processes with wetland management goals: charting a course for a sustainable future. Wetlands 28:553-562. http://dx.doi.org/10.1672/07-154.1

Fischer, J., B. Brosi, G. C. Daily, P. R. Ehrlich, R. Goldman, J. Goldstein, D. B. Lindenmayer, A. D. Manning, H. A. Mooney, L. Pejchar, J. Ranganathan, and H. Tallis. 2008. Should agricultural policies encourage land sparing or wildlife-friendly farming? Frontiers in Ecology and the Environment 6:382-387. http://dx.doi.org/10.1890/070019

Foley, J. A., N. Ramankutty, K. A. Brauman, E. S. Cassidy, J. S. Gerber, M. Johnston, N. D. Mueller, C. O’Connell, D. K. Ray, P. C. West, C. Balzer, E. M. Bennett, S. R. Carpenter, J. Hill, C. Monfreda, S. Polasky, J. Rockström, J. Sheehan, S. Siebert, D. Tilman, and D. P. M. Zaks. 2011. Solutions for a cultivated planet. Nature 478:337-342. http://dx.doi.org/10.1038/nature10452

Folke, C., T. Hahn, P. Olsson, and J. Norberg. 2005. Adaptive governance of social ecological systems. Annual Review of Environment and Resources 30:441-473. http://dx.doi.org/10.1146/ annurev.energy.30.050504.144511

Food and Agriculture Organization of the United Nations (FAO). 2009. The state of food insecurity in the world: economic crisesimpacts and lessons learned. FAO, Rome, Italy.

Grimm, N. B., S. H. Faeth, N. E. Golubiewski, C. L. Redman, J. Wu, X. Bai, and J. M. Briggs. 2008. Global change and the ecology of cities. Science 319:756-760. http://dx.doi.org/10.1126/ $\underline{\text { science. } 1150195}$

Haines-Young, R. 2009. Land use and biodiversity relationships. Land Use Policy 26(supplement 1):S178-S186. http://dx.doi. org/10.1016/j.landusepol.2009.08.009

Hannerz, F., and G. Destouni. 2006. Spatial characterization of the Baltic Sea drainage basin and its unmonitored catchments. AMBIO 35:214-219. http://dx.doi.org/10.1579/05-A-022R.1

Hoekstra, J. M., T. M. Boucher, T. H. Ricketts, and C. Roberts. 2005. Confronting a biome crisis: global disparities of habitat loss and protection. Ecology Letters 8:23-29. http://dx.doi. org/10.1111/j.1461-0248.2004.00686.x

Intergovernmental Panel on Climate Change (IPCC). 2007. Climate Change 2007: synthesis report. Contribution of working groups I, II and III to the fourth assessment report of the Intergovernmental Panel on Climate Change. R. K. Pachauri, and A. Reisinger, editors. IPCC, Geneva, Switzerland.

Intergovernmental Panel on Climate Change (IPCC). 2013. Climate change 2013: the physical science basis. Contribution of working group I to the fifth assessment report of the Intergovernmental Panel on Climate Change. T. F. Stocker, D. Qin, G.-K. Plattner, M. Tignor, S. K. Allen, J. Boschung, A. Nauels, Y. Xia, V. Bex, and P. M. Midgley, editors. Cambridge University Press, Cambridge, UK.

Jarsjö, J., S. M. Asokan, C. Prieto, A. Bring, and G. Destouni. 2012. Hydrological responses to climate change conditioned by historic alterations of land-use and water-use. Hydrology and 
Earth System Sciences 16:1335-1347. http://dx.doi.org/10.5194/ hess-16-1335-2012

Kardell, Ö., and A. Dahlström. 2013. Wolves in the early nineteenth-century county of Jönköping, Sweden. Environment and History 19:339-370. http://dx.doi.org/10.3197/096734013X1$\underline{3690716950145}$

Karlsson, B. 2014. Extended season for northern butterflies. International Journal of Biometeorology 58:691-701. http://dx. doi.org/10.1007/s00484-013-0649-8

Kautsky, U., T. Lindborg, and J. Valentin. 2013. Humans and ecosystems over the coming millennia: overview of a biosphere assessment of radioactive waste disposal in Sweden. AMBIO 42:383-392. http://dx.doi.org/10.1007/s13280-013-0405-7

Koutsouris, A. J., G. Destouni, J. Jarsjö, and S. W. Lyon. 2010. Hydro-climatic trends and water resource management implications based on multi-scale data for the Lake Victoria region, Kenya. Environmental Research Letters 5:034005. http:// dx.doi.org/10.1088/1748-9326/5/3/034005

Krauss, J., R. Bommarco, M. Guardiola, R. K. Heikkinen, A. Helm, M. Kuussaari, R. Lindborg, E. Öckinger, M. Pärtel, J. Pino, J. Pöyry, K. M. Raatikainen, A. Sang, C. Stefanescu, T. Teder, M. Zobel, and I. Steffan-Dewenter. 2010. Fragmentation causes immediate and time-delayed biodiversity loss at different trophic levels. Ecology Letters 13:597-605. http://dx.doi.org/10.1111/ j.1461-0248.2010.01457.x

Lee, E., W. J. Sacks, T. N. Chase, and J. A. Foley. 2011. Simulated impacts of irrigation on the atmospheric circulation over Asia. Journal of Geophysical Research 116:D08114. http://dx.doi. org/10.1029/2010JD014740

Liberg, O., R. Bergström, J. Kindberg, and H. von Essen. 2010. Ungulates and their management in Sweden. Pages 37-70 in M. Apollonio, R. Andersen, and R. Putman, editors. European ungulates and their management in the 21st century. Cambridge University Press, Cambridge, UK.

Lindström, A., M. Green, G. Paulson, H. G. Smith, and V. Devictor. 2013. Rapid changes in bird community composition at multiple temporal and spatial scales in response to recent climate change. Ecography 36:313-322. http://dx.doi.org/10.1111/ j.1600-0587.2012.07799.x

Mace, G. M., K. Norris, and A. H. Fitter. 2012. Biodiversity and ecosystem services: a multilayered relationship. Trends in Ecology \& Evolution 27:19-26. http://dx.doi.org/10.1016/j.tree.2011.08.006

Malinga, R., L. J. Gordon, R. Lindborg, and G. Jewitt. 2013. Using participatory scenario planning to identify ecosystem services in changing landscapes. Ecology and Society 18(4): 10. http://dx.doi.org/10.5751/ES-05494-180410

Milestad, R., L. Westberg, U. Geber, and J. Björklund. 2010. Enhancing adaptive capacity in food systems: learning at farmers' markets in Sweden. Ecology and Society 15(3): 29. [online] URL: http://www.ecologyandsociety.org/vol15/iss3/art29/

Millennium Ecosystem Assessment (MEA). 2005. Ecosystems and human well-being. Island Press, Washington, D.C., USA.
Naeem, S., J. E. Duffy, and E. Zavaleta. 2012. The functions of biological diversity in an age of extinction. Science 336:1401-1406. http://dx.doi.org/10.1126/science.1215855

Norris, K. 2011. Biodiversity in the context of ecosystem services: the applied need for systems approaches. Philosophical Transactions of the Royal Society B: Biological Sciences 367:191-199. http://dx.doi.org/10.1098/rstb.2011.0176

Nowak, D. J., D. E. Crane, and J. C. Stevens. 2006. Air pollution removal by urban trees and shrubs in the United States. Urban Forestry \& Urban Greening 4:115-123. http://dx.doi.org/10.1016/ j.ufug.2006.01.007

Nykvist, B. 2014. Does social learning lead to better natural resource management? A case study of the modern farming community of practice in Sweden. Society \& Natural Resources 27:436-450. http://dx.doi.org/10.1080/08941920.2013.861562

Olsson, P., Ö. Bodin, and C. Folke. 2010. Building transformative capacity for ecosystem stewardship in social-ecological systems. Pages 263-285 in D. Armitage, and R. Plummer, editors. Adaptive capacity and environmental governance. Springer-Verlag, Berlin, Germany. http://dx.doi.org/10.1007/978-3-642-12194-4_13

Ostrom, E. 2009. A general framework for analyzing sustainability of social-ecological systems. Science 325:419-422. http://dx.doi.org/10.1126/science.1172133

Ottvall, R., L. Edenius, J. Elmberg, H. Engström, M. Green, N. Holmqvist, А. Lindström, T. Pärt, and M. Thernberg. 2009. Population trends for Swedish breeding birds. Ornis Svecica 19:117-192.

Parmesan, C., and G. Yohe. 2003. A globally coherent fingerprint of climate change impacts across natural systems. Nature 421:37-42. http://dx.doi.org/10.1038/nature01286

Pasanen-Mortensen, M. 2014. Anthropogenic impact on predator guilds and ecosystem processes - apex predator extinctions, land use and climate change. Dissertation. Stockholm University, Stockholm. Sweden.

Quieroz, C., M. Meacham, K. Richter, A. V. Norström, E. Andersson, J. Norberg, and G. Peterson. 2015. Mapping bundles of ecosystem services reveals distinct types of multifunctinality within a Swedish landscape. AMBIO 44(Suppl 1):S89-S101. http://dx.doi.org/10.1007/s13280-014-0601-0

Rockström, J., W. Steffen, K. Noone, A. Persson, F. S. Chapin, III, E. Lambin, T. M. Lenton, M. Scheffer, C. Folke, H. J. Schellnhuber, B. Nykvist, C. A. de Wit, T. Hughes, S. van der Leeuw, H. Rodhe, S. Sörlin, P. K. Snyder, R. Costanza, U. Svedin, M. Falkenmark, L. Karlberg, R. W. Corell, V. J. Fabry, J. Hansen, B. Walker, D. Liverman, K. Richardson, P. Crutzen, and J. Foley. 2009a. Planetary boundaries: exploring the safe operating space for humanity. Ecology and Society 14(2): 32. [online] URL: http:// www.ecologyandsociety.org/vol14/iss2/art32/

Rockström, J., W. Steffen, K. Noone, Å. Persson, F. S. Chapin, III, E. Lambin, T. M. Lenton, M. Scheffer, C. Folke, H. J. Schellnhuber, B. Nykvist, C. A. de Wit, T. Hughes, S. van der Leeuw, H. Rodhe, S. Sörlin, P. K. Snyder, R. Costanza, U. Svedin, M. Falkenmark, L. Karlberg, R. W. Corell, V. J. Fabry, J. Hansen, 
B. Walker, D. Liverman, K. Richardson, P. Crutzen, and J. Foley. 2009b. A safe operating space for humanity. Nature 461:472-475. http://dx.doi.org/10.1038/461472a

Sala, O. E., F. S. Chapin, III, J. J. Armesto, E. Berlow, J. Bloomfield, R. Dirzo, E. Huber-Sanwald, L. F. Huenneke, R. B. Jackson, A. Kinzig, R. Leemans, D. M. Lodge, H. A. Mooney, M. Oesterheld, N. LeRoy Poff, M. T. Sykes, B. H. Walker, M. Walker, and D. H. Wall. 2000. Global biodiversity scenarios for the year 2100. Science 287:1770-1774. http://dx.doi.org/10.1126/ science. 287.5459 .1770

Scholes, R. J., B. Reyers, R. Biggs, M. J. Spierenburg, and A. Duriappah. 2013. Multi-scale and cross-scale assessments of social-ecological systems and their ecosystem services. Current Opinion in Environmental Sustainability 5:16-25. http://dx.doi. org/10.1016/j.cosust.2013.01.004

Sporrong, U., editor. 2008. Sveriges nationalatlas, StockholmMälarregionen. Sveriges Nationalatlas Förlag, Stockholm, Sweden.

Statistics Sweden. 1867. Befolkningsstatistik. Statistiska Centralbyråns underdåniga berättelse för året 1865 [Human population. Statistics Sweden's humble report for the year 1865]. Norstedt \& Söner, Stockholm, Sweden.

Statistics Sweden. 1868. Jordbruk och boskapsskötsel. Hushållnings-sällskapens berättelser för året 1865 [Agriculture and livestock. The agricultural society report for the year 1865]. Norstedt \& Söner, Stockholm, Sweden.

Statistics Sweden. 1879. Skogs-styrelsen underdåniga berättelse angående skogs-och jaktväsendet $i$ Sverige intill år 1870 [The national board of forestry's humble report on forestry and hunting in Sweden up until 1870]. Norstedt \& Söner, Stockholm, Sweden.

Steffen, W., P. J. Crutzen, and J. R. McNeill. 2007. The anthropocene: are humans now overwhelming the great forces of nature? AMBIO 36:614-621. http://dx.doi.org/10.1579/0044-7447 (2007)36[614:TAAHNO]2.0.CO;2

Swedish Meteorological and Hydrological Institute (SMHI). 2013. Climate data. Mean annual temperature in 1961-1990. Swedish Meteorological and Hydrological Institute, Norrköping, Sweden. [online] URL: http://www.smhi.se/klimatdata/meteorologi/ temperatur/normal-arsmedeltemperatur-1.3973

The Economics of Ecosystems and Biodiversity (TEEB). 2010. Mainstreaming the economics of nature: a synthesis of the approach, conclusions and recommendations of TEEB. Progress Press, Mriehel, Malta. [online] URL: http://www.teebweb.org/ our-publications/teeb-study-reports/synthesis-report/

van der Velde, Y., S. W. Lyon, and G. Destouni. 2013. Data-driven regionalization of river discharges and emergent land coverevapotranspiration relationships across Sweden. Journal of Geophysical Research: Atmospheres 118:2576-2587. http://dx.doi. org/10.1002/igrd.50224

van der Velde, Y., N. Vercauteren, F. Jaramillo, S. C. Dekker, G. Destouni, and S. W. Lyon. 2014. Exploring hydroclimatic change disparity via the Budyko framework. Hydrological Processes 28:4110-4118. http://dx.doi.org/10.1002/hyp.9949
Vercauteren, N., G. Destouni, C. J. Dahlberg, and K. Hylander. 2013. Fine-resolved, near-coastal spatiotemporal variation of temperature in response to insolation. Journal of Applied Meteorology and Climatology 52:1208-1220. http://dx.doi. org/10.1175/JAMC-D-12-0115.1 